\title{
Numerical Evaluation of Earthquake Effect on Cisumdawu Tunnel Stability
}

\author{
Jutika Aditya Nugraha, I Gde Budi Indrawan, and Dwikorita Karnawati \\ Department of Geological Engineering, Faculty of Engineering, Universitas Gadjah Mada, Yogyakarta, Indonesia
}

\begin{abstract}
Cisumdawu Tunnel is located approximately $3.95 \mathrm{~km}$ southeast of the active Lembang Fault. Earthquakes induced by movement of the the active the strike-slip fault may influence stability of the twin tunnel. This paper presents results of numerical analyses carried out to demonstrate effect of a worst-case scenario of earthquake load potentially induced by the Lembang Fault on the stability of the Cisumdawu Tunnel. Static and pseudo-static tunnel stability analyses were carried out at 11 observation stations of tunnel face mapping using RS2 finite element package (Rocscience, Inc.). In the pseudo-static analyses, a 0.48 horizontal seismic load coefficient, which was obtained from a deterministic seismic hazard analysis (DSHA) based on a 6.8 maximum magnitude of estimated earthquake sourced from the Lembang Fault using Campbell-Bozorgnia (2014) attenuation relationship, was applied to the finite element models. The numerical analysis results showed that strength factors of the rock masses around the twin tunnel were greater than unity, both under the static and earthquake loads. The forepolling zones, however, appeared to be under an overstressed condition. Reduction of rock strength factor around the tunnel roof due to application of the earthquake load occurred at all observation stations. Total displacement contours of rock masses around the twin tunnel indicated an increased rock mass displacement due to the earthquake load, as compared to that due to the static load. Under the static load, the largest displacement occurred at the tunnel inverts. The predicted roof displacements obtained from this study were in a reasonably good agreement with those obtained from the field measurements. Number of yielded elements and extend of shear and tension failure zones in the rock masses around the twin tunnel also appeared to increase due to the earthquake load. Despite slight tunnel displacement as predicted in the numerical analyses, the worst-case scenario of earthquake load potentially induced by the Lembang Fault may only cause failures of the rock masses around the Cisumdawu Tunnel. To prevent the twin tunnel displacement caused by such relatively severe earthquake loads, however, stabilizing surrounding the relatively poor ground condition may be necessary.
\end{abstract}

Keywords: Cisumdawu Tunnel · Displacement - Earthquake load · Pseudo-static analysis - Strength factor.

\section{INTRODUCTION}

The Cisumdawu Tunnel is located on the Cileunyi - Sumedang - Dawuan Toll Road Section (Cisumdawu) Phase II (Rancakalong -

\footnotetext{
${ }^{*}$ Corresponding author: I G. B. INDRAWAN, Department of Geological Engineering, Universitas Gadjah Mada. Jl. Grafika 2 Yogyakarta, Indonesia. E-mail: igbindrawan@ugm.ac.id
}

Sumedang) at the STA. $12+628-$ STA. $13+100$ (Figure 1). Referring to the Earthquake Map of Indonesia (National Earthquake Research Center, 2017), the $12 \mathrm{~m}$ high, $15.7 \mathrm{~m}$ diameter twin tunnel is located approaximately $3.95 \mathrm{~km}$ southeast of the active Lembang Fault. A number of researchers have investigated movement of the Lembang Fault. For instance, Daryono 
(2016) based on tectonic geomorphology and paleoseismology methods suggested the slip rate of the strike-slip fault ranging from 2 to 6 $\mathrm{mm} / \mathrm{yr}$. National Earthquake Research Center (2017) estimated the Lembang Fault potentially caused a 6.8 maximum magnitude of earthquake. Earthquakes induced by movement of the the active Lembang Fault may influence the stability of the Cisumdawu Tunnel.

Numerical stability analyses of tunnels subjected to earthquake loads are commonly carried out using pseudo-static analysis and dynamic analysis approaches. In the pseudostatic analysis approach, ground motion parameters are represented by constant horizontal and/or vertical seismic (earthquake) accelerations and the ground deformations are imposed as a static load. The pseudo-static analysis is relatively simple and straightforward. The soil-underground structure interaction, however, does not include dynamic or wave propagation effects (e.g., Kramer, 1996; Hashash et al., 2001). In the pseudo-static analysis, earthquake load is applied by assigning a seismic coefficient, which is dimensionless coefficient and represents the peak earthquake acceleration as a fraction of the acceleration due to gravity. Peak earthquake acceleration can be determined using deterministic seismic hazard analysis (DSHA) and probabilistic seismic hazard analysis (PSHA) (Hung et al., 2009). A DSHA aims at finding the combination of the maximum possible earthquake magnitude and the corresponding distance which would generate the highest level of ground motion at a site of interest. It provides a straightforward framework for evaluation of worst-case ground motions. However, it provides no information about the probability or frequency of occurrence of the controlling earthquake. The PSHA, on the other hand, incorporates the uncertainties in sourceto-site distance, magnitude, rate of recurrence and the variation of ground motion characteristics into the analyses (Kramer, 1996; Hashash et al., 2001; Gupta, 2002).

Several studies have been carried out to evaluate construction of the Cisumdawu Tunnel. For instance, Halomoan (2018) evaluated the engineering geological conditions and effects of excavation method and support system on the twin tunnel deformation. Umbara et al.
(2019) evaluated the excavation methods of the Cisumdawu Tunnel by numerical approach. The Cisumdawu Tunnel was initially designed empirically and stability analyses of the twin tunnel under earthquake loads have never been conducted.

This paper presents results of numerical analyses carried out to demonstrate effect of a worst-case scenario of earthquake load potentially induced by the movement of the Lembang Fault on the stability of the Cisumdawu Tunnel. Strength factors and total displacements of rock masses around the twin tunnel resulted from static and pseudo-static tunnel stability analyses are presented. Deformation of the twin tunnel subjected to a seismic coefficient determined by the DSHA is highlighted.

\section{METHOD}

Input data for the numerical analyses were obtained from core drilling during design stage and face mapping during tunnel excavation. Core drilling was carried out at 15 locations along the tunnel line by the Cisumdawu Toll Road Contractor (Metallurgical Corporation of China, Ltd) (Figure 2). Face mapping of tunnel excavation was carried out at 11 observation stations (STA), namely STA. 12+658.8, STA. $12+662.4$, STA. $12+667$, STA. 12+672, STA. $12+674.3$, STA. $12+676.5$, STA. $12+678.5$, STA. $12+681.3$, STA. $12+682$, STA. $12+682.5$ and STA. 12684 . Soil sampling for laboratory tests of the engineering properties was conducted at every observation stations.

The results of core drilling and face mapping showed that the Cisumdawu Tunnel and its surroundings consisted of tuff breccia that have undergone high to complete weathering so that they were dominated by residual soil. Core drilling records compiled by CV. Geocipta Bangun Optima (2014 and 2016) and Geotechnical Engineering Consultant (2012) showed that the tuff breccia along the tunnel alignment had different engineering properties so that it could be divided into three layers, namely tuff breccia 1, tuff breccia 2, and tuff breccia 3 (Figure 3 ). The groundwater levels were located at depths ranging ranges from 24.7 to $24.93 \mathrm{~m}$ and lowered during the twin tunnel construction.

Numerical analyses were performed in two dimensions using the finite element method in 


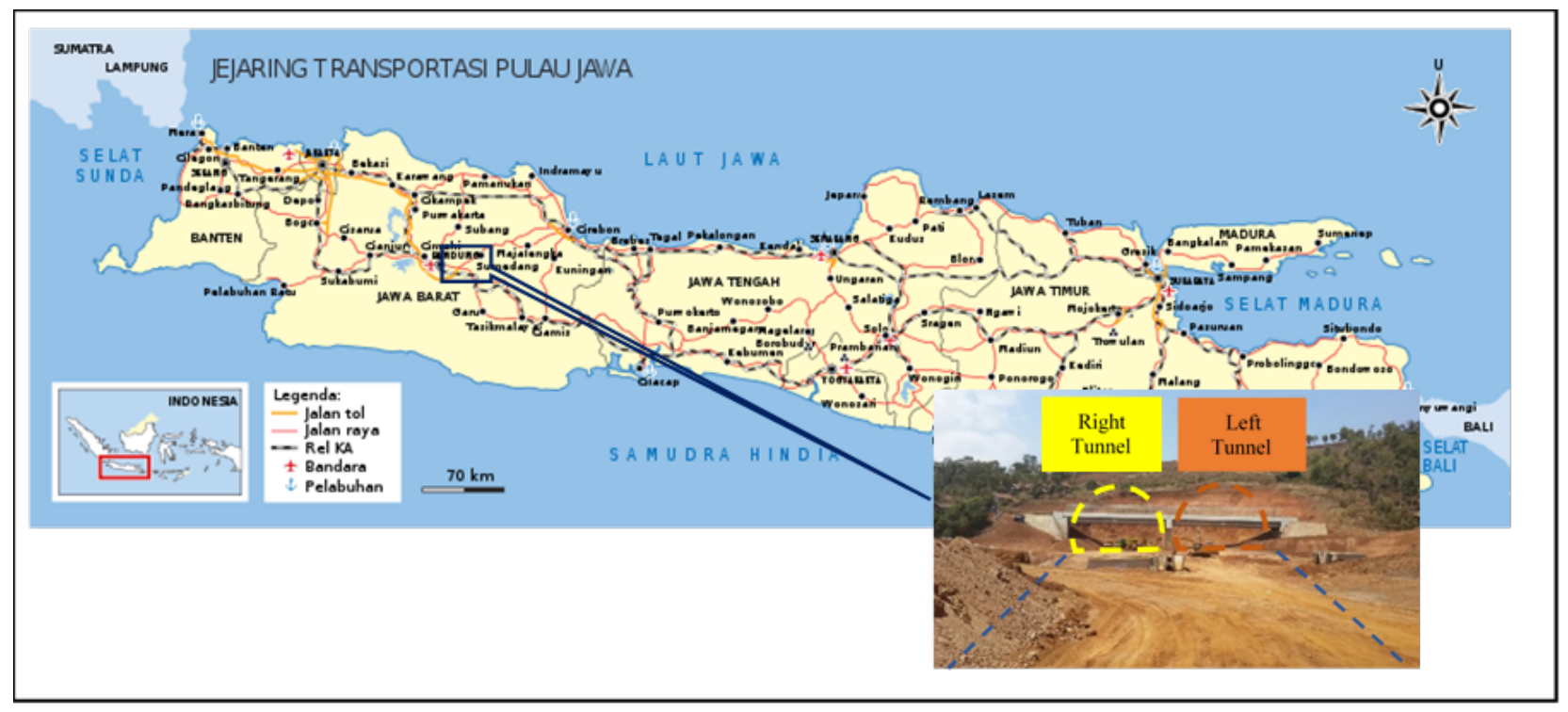

Figure 1: Location of Cisumdawu Tunnel.

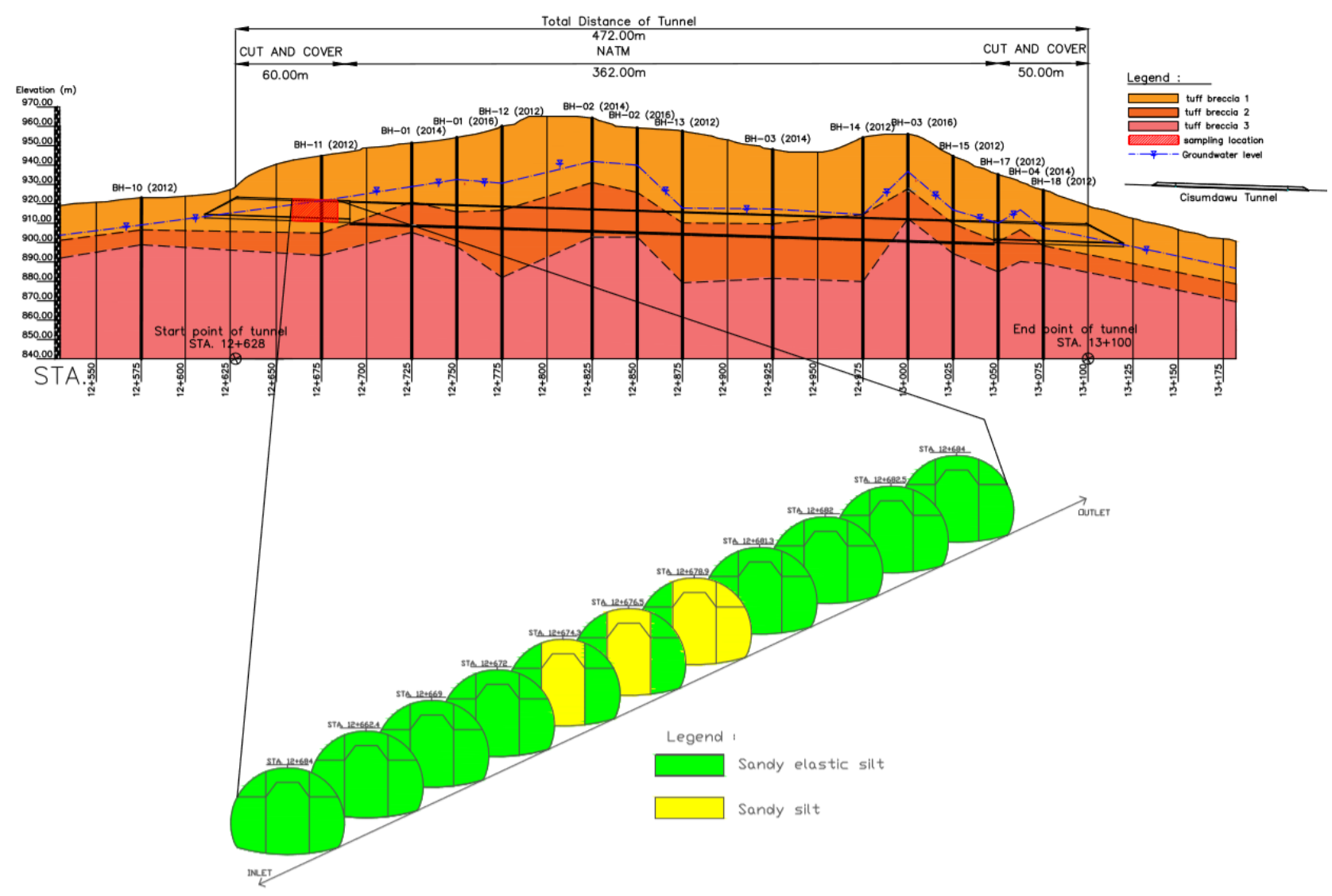

Figure 2: Rock layer, bore hole location, and facemap data. 


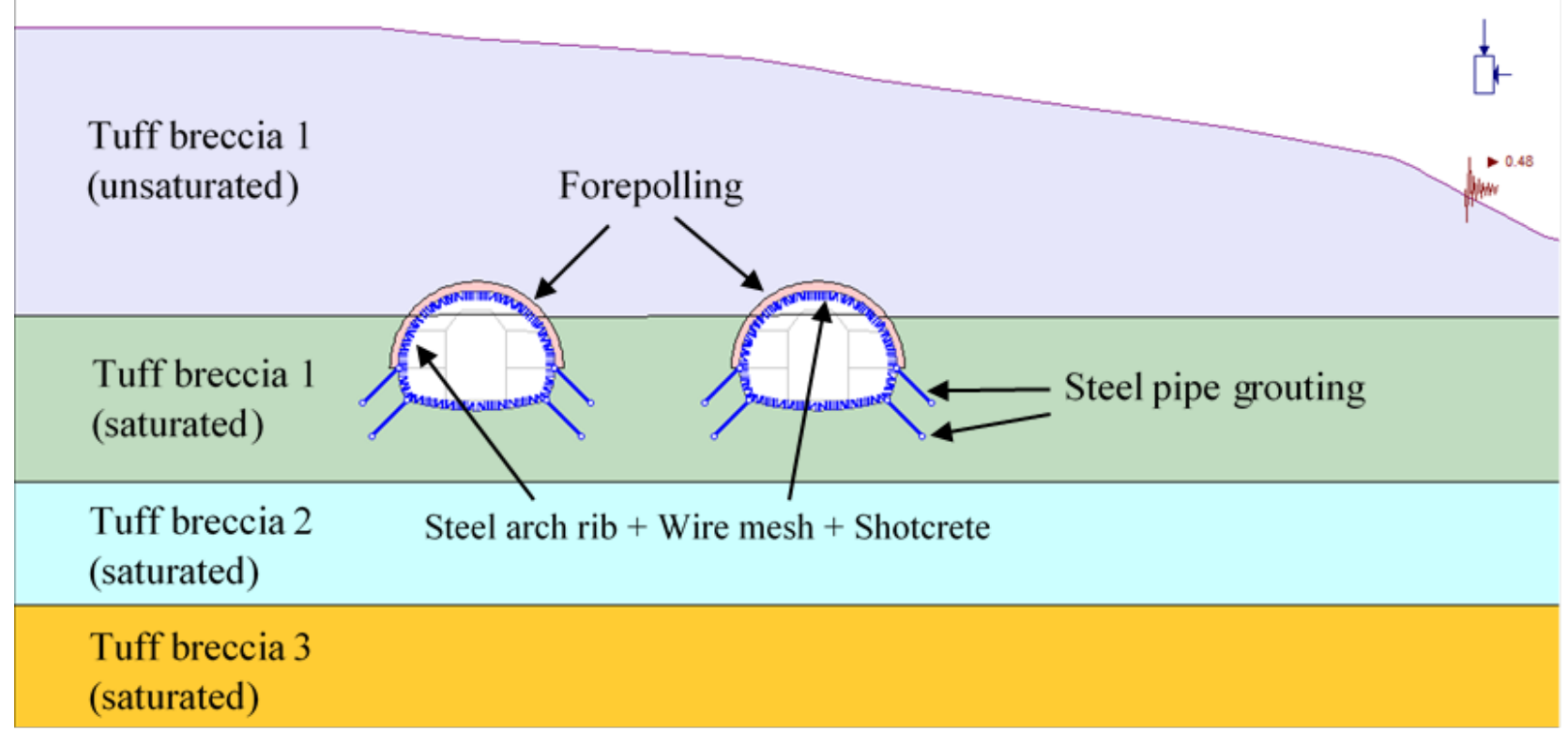

Figure 3: Simplified geometry of finite element model.

RS2 software package (Rocscience, Inc.). Simplified geometry of the finite element models is shown in Figure 3. Distance between the twin tunnels was taken from the midpoint of each tunnel. The sides of the outer boundary conditions were set at a distance of 10 times the tunnel radius and allowed to shift vertically. The bottom was set at a distance of 5 times the tunnel radius and restrained in $\mathrm{x}$ and $\mathrm{y}$ directions, while the top was set at the actual ground surface elevation and unrestrained. Stages of tunnel excavations in the numerical analyses followed those in the field. Properties of the tuff breccia layers are shown in Table 1. The shear strength parameters (cohesion and friction angle) were obtained from laboratory triaxial consolidated-undrained (CU) tests. Properties of the support systems provided by KSO PT. Hi Way Indotek and JO. PT. Wahana Mitra Amerta (2014) are shown in Table 2. Forepolling reinforcement was modeled as a composite material following a method proposed by Hoek (2000). The rock layers were assumed to have plastic behavior, while the support systems were assumed to have elastic behavior.

A gravity type of field stress was applied as the tunnel location was considered relatively shallow. Because direct measurement of in situ stresses was not carried out, the values for vertical and horizontal stresses in the finite element models were estimated. Vertical stress was au- tomatically calculated based on the thickness of overburden. Meanwhile, the horizontal stress was calculated using a stress ratio $(\mathrm{k})$ calculated using the coefficient of earth pressure at rest (k0) by Jaky (1944). The meshes were generated automatically where the finite element models were divided into more than 2,200 triangular nodes.

Since ground acceleration due to earthquake originated from the Lembang Fault was of particular interest in this study, a deterministic seismic hazard analysis (DSHA) was carried out based on a 6.8 maximum magnitude of estimated earthquake sourced from the Lembang Fault using Campbell-Bozorgnia (2014) attenuation relationship, following data and procedures described in National Earthquake Research Center (2017). Detailed calculations of the DSHA were described in Nugraha (2019). The DSHA result indicated that the Cisumdawu Tunnel was potentially subjected to a 0.48 $\mathrm{g}$ horizontal ground acceleration. To investigate effect of the earthquake on the twin tunnel stability, therefore, a 0.48 horizontal seismic load coefficient was applied to the finite element models, while vertical component of seismic load was assumed to be small. The horizontal seismic load coefficient may represent a worst-case scenario of earthquake load applied to the Cisumdawu Tunnel. Tunnel stability was 
Table 1: Properties of rock layers.

\begin{tabular}{|c|c|c|c|c|c|c|}
\hline Layer & $\begin{array}{c}\gamma \\
\left(\mathrm{kN} / \mathrm{m}^{3}\right)\end{array}$ & $E(\mathrm{kPa})$ & $c(\mathrm{kPa})$ & $\phi(0)$ & $v$ & $K_{0}$ \\
\hline Tuff breccia 1 (unsaturated) & 14.1 & 53039.92 & 40.21 & 25.7 & 0.3 & \multirow{4}{*}{0.5} \\
\hline Tuff breccia 1 (saturated) & 15.8 & 57074.7 & 40.6 & 27.75 & 0.3 & \\
\hline Tuff breccia 2 (saturated) & 16.3 & 58055.37 & 35.8 & 31.5 & 0.3 & \\
\hline Tuff breccia 3 (saturated) & 16.3 & 58545.7 & 44.13 & 31 & 0.3 & \\
\hline
\end{tabular}

Note: $\gamma=$ unit weight; $E=$ Young's modulus; $c=$ cohesion; $\phi=$ friction angle; $v=$ Poisson's ratio; $K_{0}=$ horizontal stress ratio.

inferred from the strength factor and total displacement values at 11 observation stations.

\section{RESUlTS AND DisCUSSION}

Typical strength factor contours of rock masses around the twin tunnel subjected to static and earthquake loads are shown in Figure 4. In general, strength factors of the rock masses around the twin tunnel both under the static and earthquake loads were greater than unity. Both under static and earthquake loads, strength factors in the forepolling zones appeared to be less than unity, indicating overstressing. Strength factors of the rock masses around the tunnel roofs at all observation stations are shown in Table 3. Under the static load, the roof strength factors ranged from 1.72 to 1.97 . Under the applied earthquake load, the roof strength factors ranged from 1.1 to 1.106. Reduced rock strength factor around the tunnel roof due to the earthquake load occurred at all observation stations.

Total displacement contours of the rock masses around the twin tunnel subjected to static and earthquake loads indicate an increased rock displacement due to earthquake load (Figure 5). Under the static load, total displacements of the rock masses around the twin tunnel ranges from 0 to $0.13 \mathrm{~m}$ and the largest displacement occurs at the tunnel inverts. Total displacement at the invert of the right tunnel was slightly higher than that of the left tunnel (Figure 5(a)). Under the earthquake load, total displacements of the rock masses ranges from 0.88 to $1.32 \mathrm{~m}$. Total displacements of the rock masses around the tunnel roofs at all observation stations are presented in Table 3. Under the static load, the roof displacements at all STA ranged from 0.075 to $0.0975 \mathrm{~m}$. Field measurement data at nearby observation sta- tions (i.e., STA $12+649.6$ to $12+654$ ) presented in Umbara et al. (2019) indicated that the roof displacements were approximately 0.024 to $0.029 \mathrm{~m}$. The predicted roof displacements obtained from this study were, therefore, in a reasonably good agreement with those obtained from the field measurements. Under the earthquake load, the roof displacements at all observation stations ranged from 1.17 to 1.23 $\mathrm{m}$. Number of yielded elements and extend of failure zones (shear and tension) in the rock masses around the twin tunnel also appeared to increase due to the earthquake load. Figure 6 shows slight deformation of the twin tunnel to the right, in response to application of the positive horizontal seismic load. Under relatively severe earthquake load, however, the twin tunnel structural integrity appeared to be still maintained. To prevent the twin tunnel displacement in response to such relatively severe earthquake loads, however, stabilizing surrounding the relatively poor ground condition may be necessary.

It is important to note that the seismic load coefficient applied in this study was obtained from a DSHA based on a 6.8 maximum magnitude of estimated earthquake sourced from the Lembang Fault. As suggested in a number of publications (e.g., Kramer, 1996; Hashash et al., 2001), ground motion parameters obtained from DSHA represented a worst-case scenario of earthquake. Furthermore, the maximum possible ground motion at a site obtained from DSHA may not occur during life period (Gupta, 2002). Further numerical analyses incorporating a PSHA-determined earthquake load are suggested to understand stability condition of the Cisumdawu Tunnel under a more realistic earthquake load. 
NUGRAHA et al.
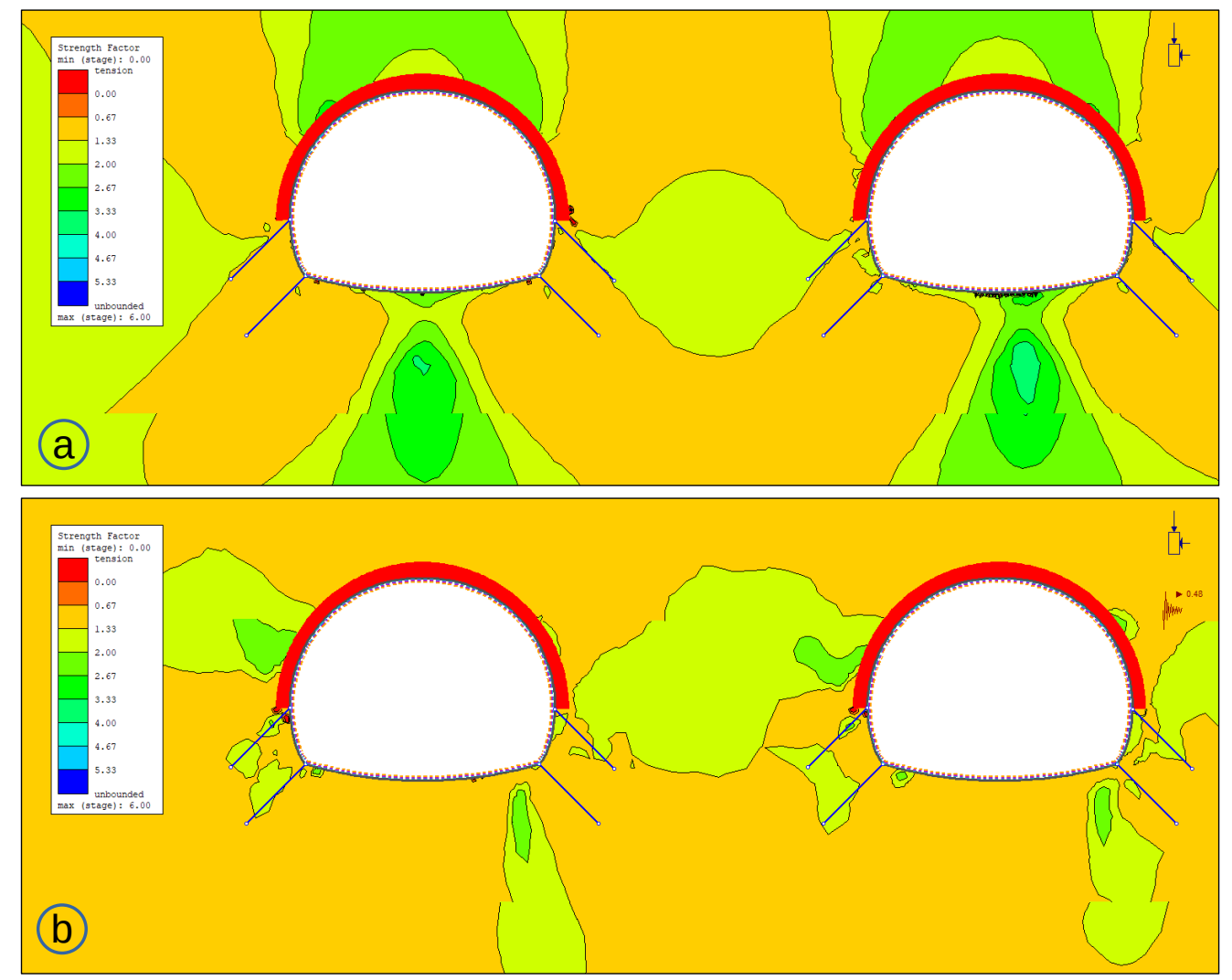

Figure 4: Strength factor contours at STA 12+658.8 under (a) static and (b) earthquake loads.
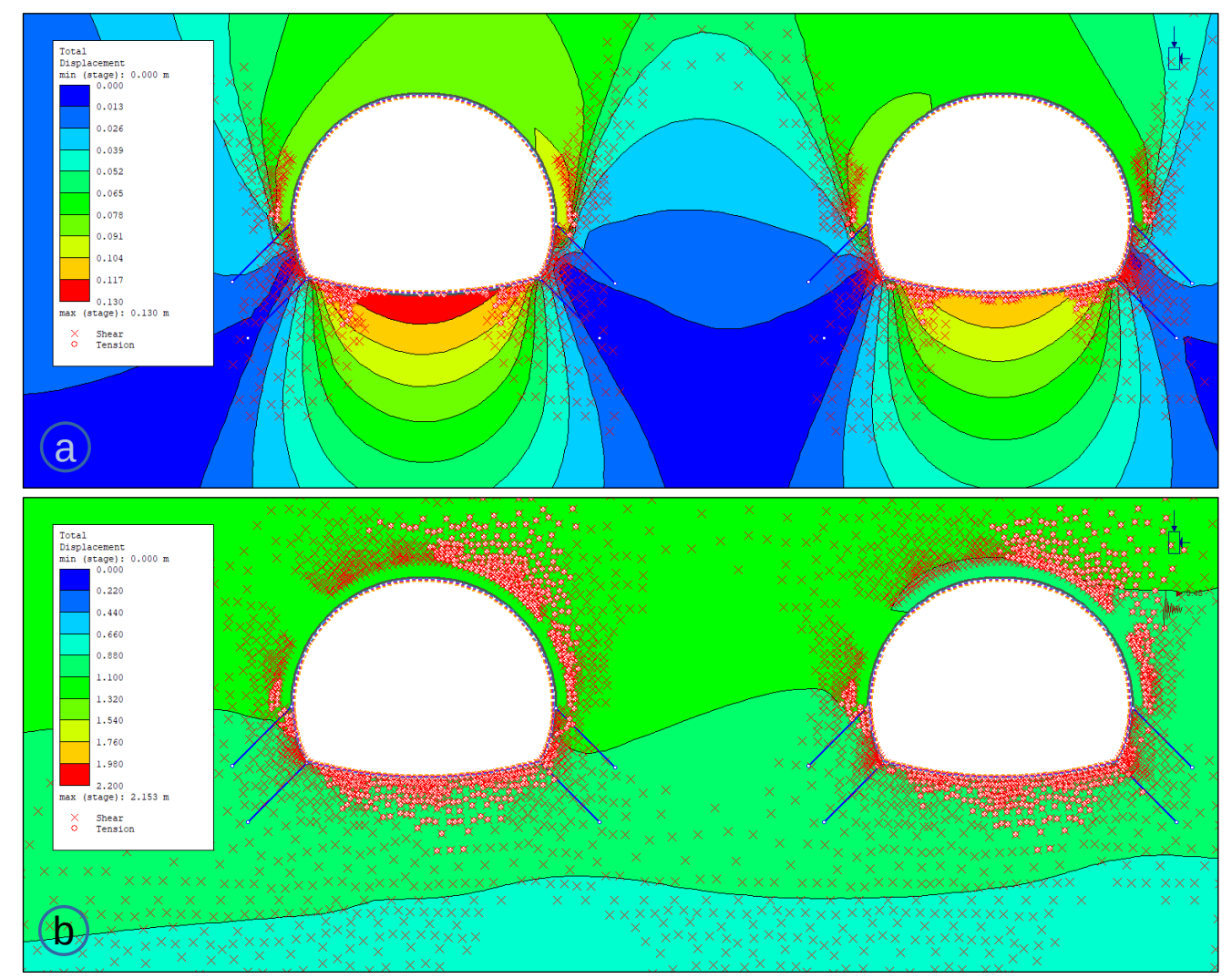

Figure 5: Displacement contours at STA 12+658.8 under (a) static and (b) earthquake loads. 

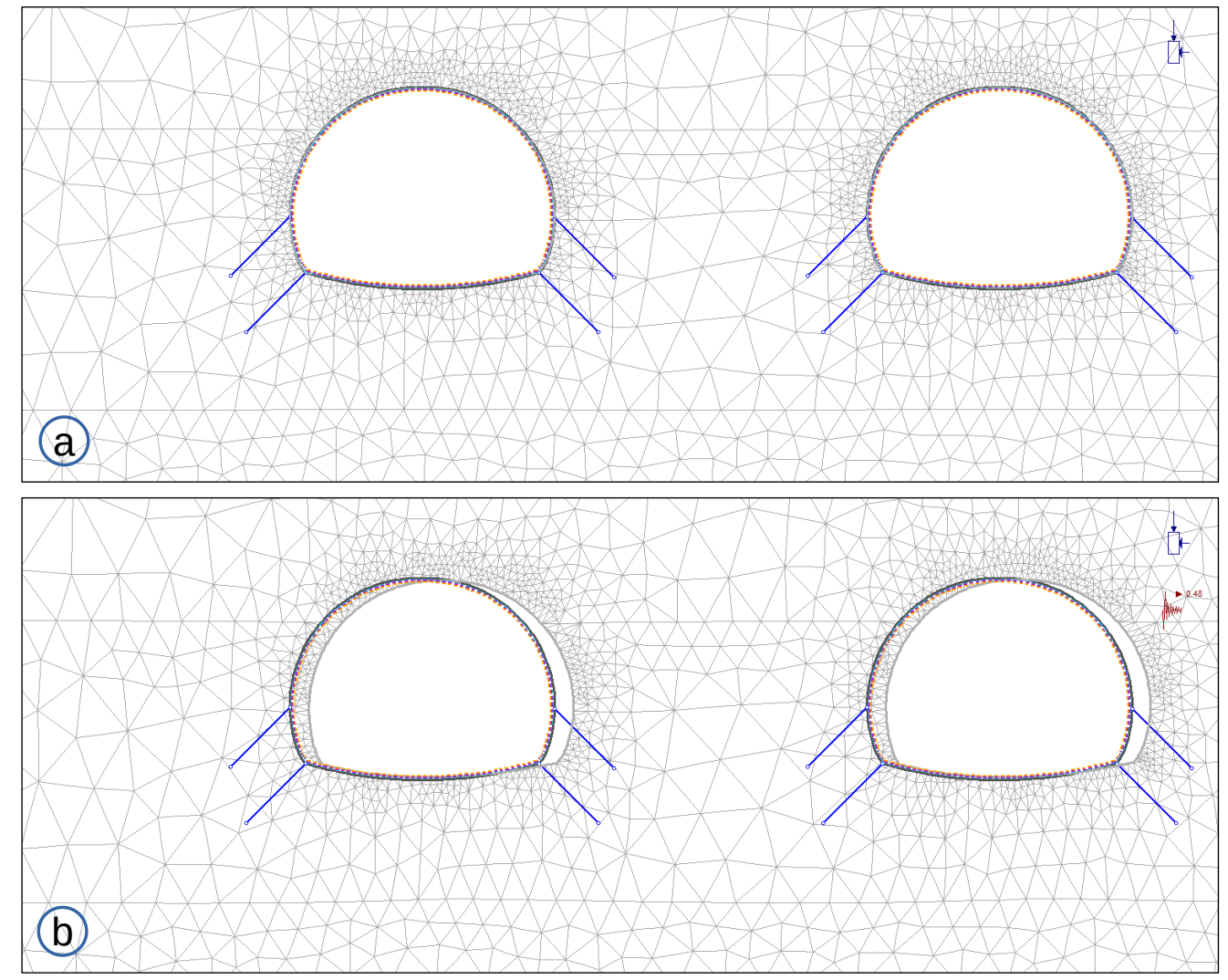

Figure 6: Deformed mesh and boundaries of the twin tunnel under (a) static and (b) earthquake loads.

\section{CONCLUSION AND RECOMMENDATION}

Static and pseudo-static numerical analyses were carried out at 11 observation stations of tunnel face mapping using a finite element method to demonstrate effect of a worst-case scenario of earthquake load on the stability of the Cisumdawu Tunnel. The numerical analysis results showed that strength factors of the rock masses around the twin tunnel were greater than unity, both under the static and earthquake loads. The forepolling zones, however, appeared to be under an overstressed condition. Reduction of rock strength factor around the tunnel roof due to application of the earthquake load occurred at all observation stations. Total displacement contours of rock masses around the twin tunnel indicated an increased rock mass displacement due to the earthquake load, as compared to that due to the static load. Under the static load, the largest displacement occurred at the tunnel inverts. Total displacement at the invert of the right tunnel was slightly higher than that of the left tunnel. The predicted roof displacements obtained from this study were in a reasonably good agreement with those obtained from the field measurements. Number of yielded elements and extend of shear and tension failure zones in the rock masses around the twin tunnel also appeared to increase due to the earthquake load.

Despite slight tunnel displacement as predicted in the numerical analyses, the worst-case scenario of earthquake load potentially induced by the Lembang Fault may only cause failures of the rock masses around the Cisumdawu Tunnel. To prevent the twin tunnel displacement in response to such relatively severe earthquake loads, however, stabilizing surrounding the relatively poor ground condition may be necessary. Further numerical analyses incorporating a PSHA-determined earthquake load are suggested to understand stability condition of the Cisumdawu Tunnel under a more realistic earthquake load.

\section{ACKNOWLEDGEMENTS}

The authors would like to thank Satuan Kerja Pelaksanaan Jalan Bebas Hambatan Cisum- 


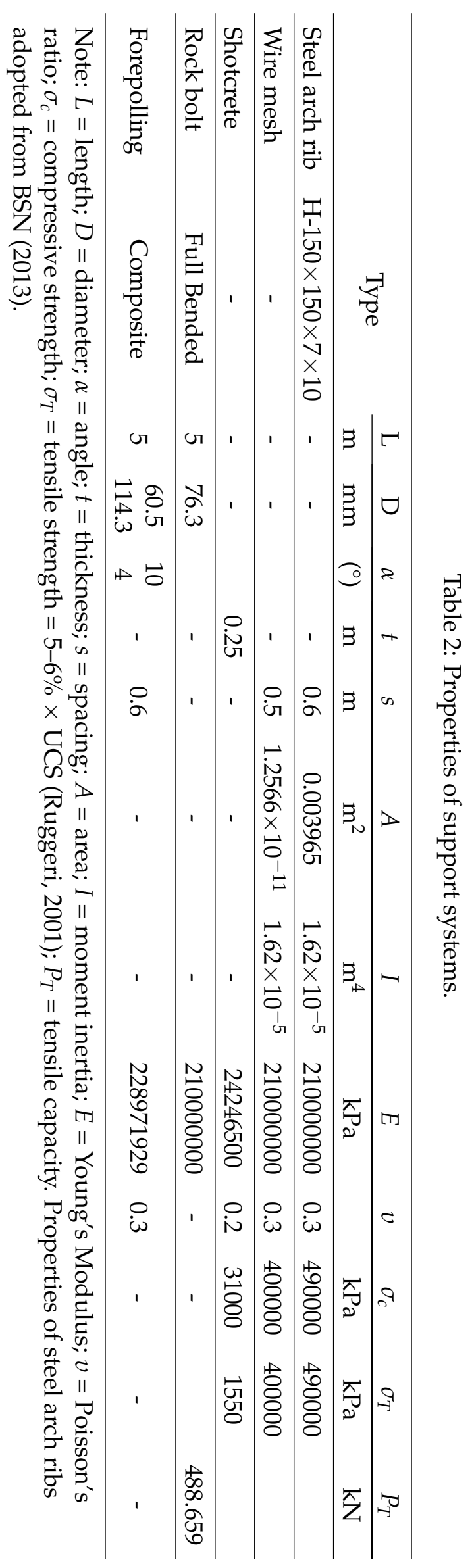


dawu dan Balai Besar Pelaksanaan Jalan Nasional VI Jakarta, Bina Marga Directorate General, the Ministry of Public Works and Housing of Indonesia for permission conducting this research. The first author would also like to thank the Ministry of Public Works and Housing of Indonesia for the scholarship. Assistance of Mr. Pande Made Oka Dwi Warma Putra in conducting field and laboratory works is gratefully acknowledged.

\section{REFERENCES}

Campbell, K.W. and Bozorgnia, Y. (2014) NGAWest2 Ground Motion Model for the Average Horizontal Components of PGA, PGV, and 5\% Damped Linear Acceleration Response Spectra. Earthquake Spectra: August 2014, Vol. 30, No. 3, p. 1087-1115.

Daryono, M. R. (2016) Paleoseismology Tropis Indonesia: Dengan Studi Kasus di Sesar Sumatra, Sesar Palukoro-Matano, dan Sesar Lembang. Unpublished Dissertation. Institut Teknologi Bandung.

Gupta, I.D. (2002) The State of the Art in Seismic Hazard Analysis. ISET Journal of Earthquake Technology 428 (39) No. 4, p. 311-346.

Halomoan, R. P. (2018) Analisis Metode Penggalian dan Kestabilan Terowongan Jalan Tol Cisumdawu (Cileunyi - Sumedang - Dawuan), Provinsi Jawa Barat. Unpublished Thesis. Universitas Gadjah Mada, Yogyakarta.

Hashash, Y.M.A., Hook, J.J., Schmidt, B., and Yao, J. I-C. (2001) Seismic Design and Analysis of Under- ground Structures. Tunnelling and Underground Space Technology 16, p. 247-293.

Hoek, E. (2000) Numerical Modelling for Shallow Tunnels in Weak Rock. Presented during the 5th GRC Lecture, NTU, Singapore.

Hung, C.J., Monsees, J., Munfah, N., and Wisniewski, J. (2009) Technical Manual for Design and Construction of Road Tunnels. FHWA-NHI10-034. National Highway Institute, U.S. Department of Transportation.

Jaky, J. (1944) The Coefficient of Earth Pressure at Rest. Journal of the Society of Hungarian Architects and Engineers, vol. 7, p. 355-358.

Kramer, S.L. (1996) Geotechnical Earthquake Engineering. Prentice-Hall, Inc.

KSO PT. Hi Way Indotek, \& JO. PT. Wahana Mitra Amerta (2014) Perencanaan Teknik Terowongan Cisumdawu (Final Design).

National Earthquake Research Center (2017) Peta Sumber dan Bahaya Gempa Indonesia Tahun 2017. Bandung: Puslitbang Kementerian PUPR.

Nugraha, J. A. (2019) Analisis dan Mitigasi Risiko Deformasi Terowongan Sisi "L" di STA 12+684 hingga STA 12+658, Jalan Tol Cisumdawu-Jawa Barat. Unpublished Thesis. Universitas Gadjah Mada, Yogyakarta.

Ruggeri, G. (2001) Sliding Safety of Existing Gravity Dams - Final Report. BSN. 2013. SNI Standar Nasional Indonesia 0068:2013. Pipa Baja untuk Konstruksi Umum. Jakarta.

Umbara, R., Indrawan, I.G.B., Aldiamar, F. (2019) Numerical Evaluation of Cisumdawu Tunnel Excavation Method. Jurnal Jalan-Jembatan 36 (1), p. 54-66. 